\title{
FIVE NEW DIPLOMMATINIDAE OF THE GENERA ARINIA H. ET A. ADAMS, 1856, NOTHARINIA VERMEULEN, PHUNG ET TRUONG, 2007, AND OPISTHOSTOMA W. T. BLANFORD ET H. BLANDFORD, 1860 (GASTROPODA: CAENOGASTROPODA) FROM BORNEO
}

\author{
JAAP J. VERMEULEN ${ }^{1 *}$, MOHD ZACAERY KHALIK ${ }^{2}$
}

\footnotetext{
${ }^{1}$ JK Art and Science, Lauwerbes 8, 2318 AT Leiden, Netherlands (e-mail: jk.artandscience@gmail.com); (1) https://orcid.org/0000-0002-8505-0319

${ }^{2}$ Faculty of Resource Science and Technology, Universiti Malaysia Sarawak, 94300 Kota Samarahan,

Sarawak, Malaysia; (1) https://orcid.org/0000-0001-7098-0743

* corresponding author
}

ABSTRACT: Five new species are described: Arinia bathyodon sp. nov., A. congener sp. nov., A. semiconica sp. nov., Notharinia xenos sp. nov. and Opisthostoma hemituba sp. nov., all belonging to the family Diplommatinidae. They occur on limestone hills in Borneo: Sarawak (Malaysia) and East Kalimantan (Indonesia).

KEY WORDS: land snails; Malaysia; Indonesia; Borneo

Publication LSID urn:lsid:zoobank.org:pub:18B7B3F0-D4DD-4580-A74A-D03FC2515CBE

\section{INTRODUCTION}

We describe five new species of the family Diplommatinidae originating from the island of Borneo (Malaysia: Sarawak; Indonesia: Kalimantan). At first sight, they all resemble the genus Arinia $\mathrm{H}$. Adams et A. Adams, 1856, but closer inspection of the shells reveals this holds true for three only. The fourth species lacks the diagnostic character of the genus Arinia: a constriction in the body whorl which, in Arinia, is provided inside with a thickened calcareous ring. Therefore, we place it in the genus Notharinia Vermeulen, Phung et Truong, 2007 (N. xenos sp. nov.), a surprising novelty at the genus level for Borneo, well outside the known range of Notharinia (Laos and Cambodia). This distribution pattern inspires speculations that this character loss occurred twice and that inclusion of N. xenos in Notharinia would render the genus polyphyletic, but until the phylogenetic structure of the group is elucidated, we are inclined to the most parsimonious option, which is to include the new species in Notharinia. Finally, the fifth species displays, rather inconspicuously, a curvature of the last part of the body whorl (the tuba) diagnostic for Opisthostoma W. T. Blanford et H. Blandford, 1860 (O. hemituba sp. nov.).

\section{MATERIAL AND METHODS}

The material studied derives from the private collection of the first author (' $\mathrm{V}$ ' in the lists of ex- amined material below). The holotypes are stored in the Zoological Museum (MZU) of the Universiti 
Malaysia Sarawak (UNIMAS). The descriptions follow the format and terminology of VERMEULEN \& LIEW (2022). The illustrations are by the first author, with the aid of a Wild M8 stereo microscope with a Camera Lucida device. He claims copyright of the illustrations.

\section{TAXONOMIC PART}

\section{Family Diplommatinidae L. Pfeiffer, 1857}

\section{Arinia H. Adams et A. Adams, 1856}

The Borneo species of the genus are revised in VERMEULEN (1996). This source also provides diagnostic sets for diplommatinid genera in Borneo, as well as an identification key.

\section{Arinia bathyodon sp. nov.}

Figs 1-4

urn:Isid:zoobank.org:act:FA71490E-E892-4250-9408-96A5435C6CD4

Examined material. Indonesia: Kalimantan Timur. Sangkulirang peninsula, surroundings of Lempake, 1998 (holotype: MZU.MOL.21.07, paratypes: V5984/>10 shells).

Diagnosis. A. bathyodon sp. nov. resembles A. dentifera Vermeulen, 1996 in its general shape and the presence of a columellar tooth deep inside the aperture. A. bathyodon differs in the presence of single-crested radial ribs only, as well as in a longer tuba (3/4-7/8 whorl, versus $1 / 2-5 / 8$ whorl). In the key to the Borneo Arinia in Vermeulen (1996), A. bathyodon keys out with the species complex of $A$. stenotrochus Vermeulen, 1996. It differs from A. stenotrochus in the presence of a columellar tooth. Generally, it is distinguished among the Borneo Arinia by the long tuba: $3 / 4-7 / 8$ whorl, versus $3 / 4$ whorl at most, except $A$. streptaxiformis Vermeulen, 1996 which has an even longer tuba. From the latter it is immediately distinguished by the closed umbilicus.

Description. Shell ellipsoid-cylindrical to almost cylindrical, last two whorls widest in frontal view. Whorls convex. Constriction present, without teeth. Tuba with a longitudinal columellaris deep inside, almost invisible in frontal view. Sculpture of radial ribs, all single-crested, down to the penultimate whorl with $8-12$ ribs $/ 0.5 \mathrm{~mm}$, absent above the aperture; on the tuba $5-8$ ribs $/ 0.5 \mathrm{~mm}$. Spiral striation absent. Aperture not or hardly turned upwards. Peristome: palatal side slightly protruding beyond the penultimate whorl or not, columellar side not sinuous; outer peristome moderately spreading beyond the inner one on the palatal and basal side, gradually narrowed on the columellar side, rather gradually to rather abruptly narrowed towards the upper corner; inner peristome just above the upper corner without protrusion, without furrow, palatal and basal side without lip parallel to the margin. Umbilicus closed. Dimensions: height 1.2-1.6 mm; width 0.75$0.90 \mathrm{~mm}$; height/width ratio 1.50-1.93; number of whorls $41 / 8-5$, including the tuba of $3 / 4-7 / 8$ whorl; aperture height $0.35-0.40 \mathrm{~mm}$; width $0.30-0.40 \mathrm{~mm}$. Ecology. High primary rainforest on limestone plateau. Altitude 200-300 m a.s.l.

Distribution. Indonesia, Kalimantan Timur, Sangkulirang Peninsula.

Etymology. From Ancient Greek: ' $\beta \alpha \theta v \varsigma^{\prime}$ deep, and 'ódov́s', tooth.

\section{Arinia congener sp. nov.}

Figs 5-7

urn:Isid:zoobank.org:act:6D6AF3EB-E2E2-4330-AA5A-A760460D86D6

Examined material. Malaysia: Sarawak. 4th Division, Gunung Mulu National Park, along path from Clearwater cave to Moonmilk cave, 2003 (holotype: MZU.MOL.21.08, paratypes: V10414/>10 shells).

Diagnosis. A. congener sp. nov. most resembles $A$. pertusa Vermeulen, 1996, and keys out next to this species in VermeUlen (1996); it differs from A. pertusa in its smaller size (shell height $1.0-1.2 \mathrm{~mm}$, versus $1.3-1.85 \mathrm{~mm}$; aperture height $0.25-0.35 \mathrm{~mm}$; width $0.25-0.30 \mathrm{~mm}$, versus $0.35-0.45 \mathrm{~mm}$ and $0.30-0.40$ $\mathrm{mm}$ ), and in the tuba length (c. 5/8 whorl versus 3/8-1/2 whorl). A. ferecognita Vermeulen, 1996, keys out in the same couplet in VerMEULEN (1996); A. congener differs in the outer peristome which is more abruptly narrowed towards the parietal side, both on the columellar and the palatal side. A. congener also differs in a longer tuba (c. 5/8 whorl versus c. $3 / 8$ whorl). It also resembles sympatric $A$. similis $\mathrm{E}$. A. Smith, 1893, from which it differs in a narrower shell (shell width $0.75-0.80 \mathrm{~mm}$, versus $0.90-1.10 \mathrm{~mm}$ ), a longer tuba (c. 5/8 whorl, versus $1 / 4-1 / 2$ whorl), and in the absence of any callosities on the inner peristome, in the angular corner of the aperture.

Description. Shell shortly ellipsoid-cylindrical, body whorl or last two whorls widest in frontal view. Whorls convex. Constriction present, without teeth. Tuba without teeth. Sculpture of radial ribs, single-crested, down to approx. the second half of penultimate whorl, with $12-17$ ribs $/ 0.5 \mathrm{~mm}$, from there down to the tuba with $5-8$ ribs $/ 0.5 \mathrm{~mm}$; on the tuba 5-7 ribs $/ 0.5 \mathrm{~mm}$. Spiral striation absent. Aperture not or very slightly turned upwards. Peristome: pal- 


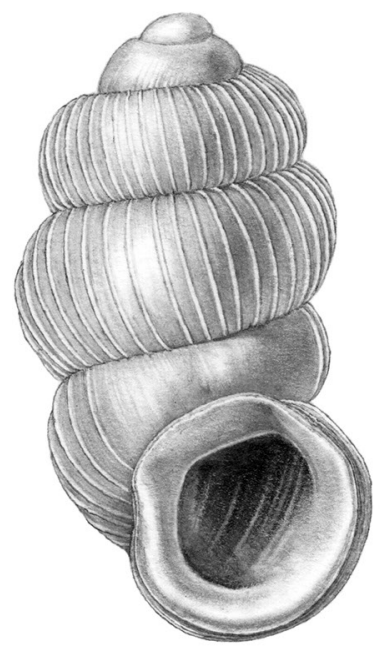

1
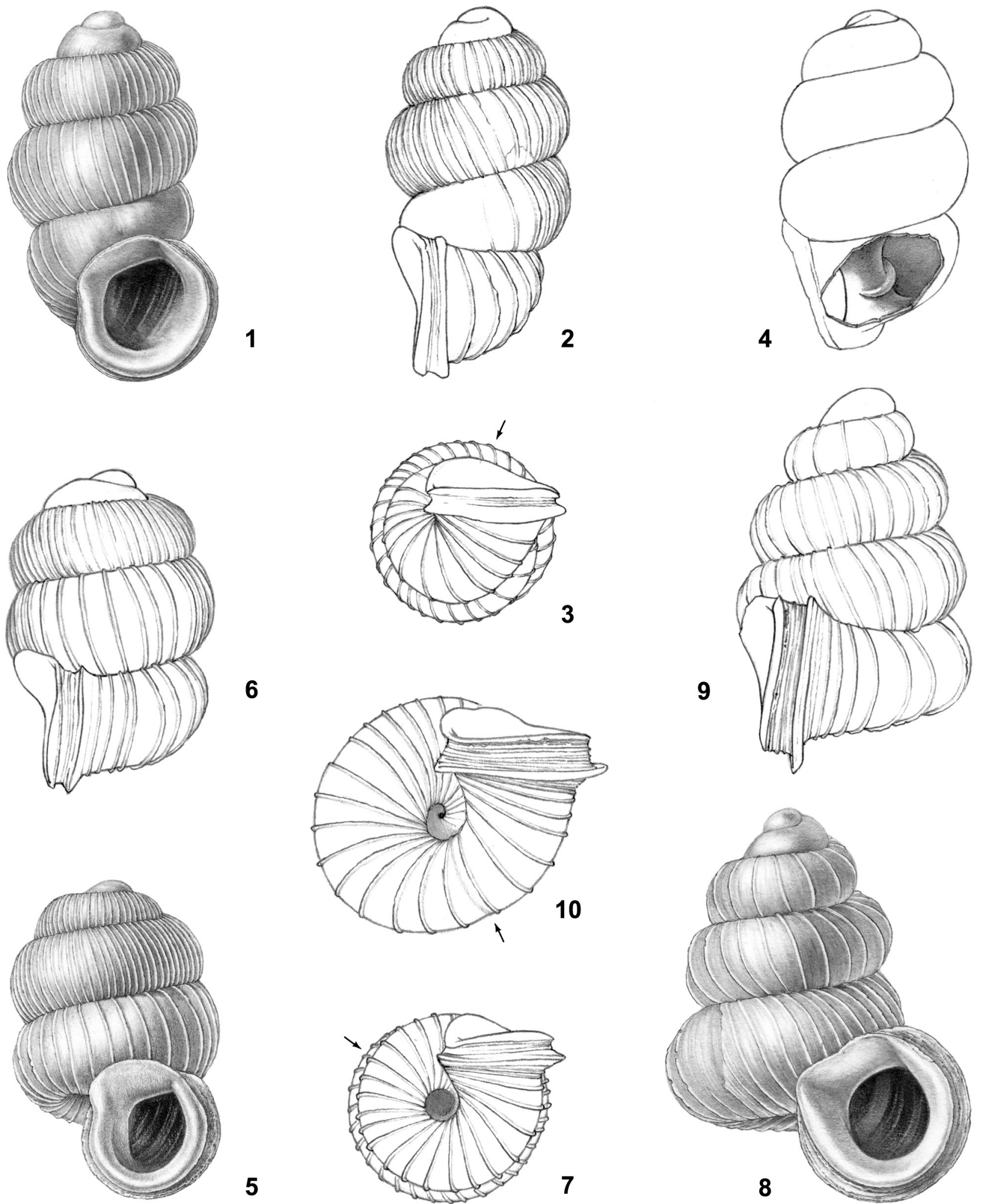

6

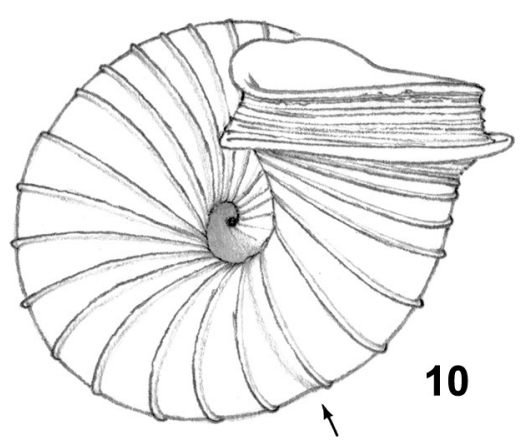

5
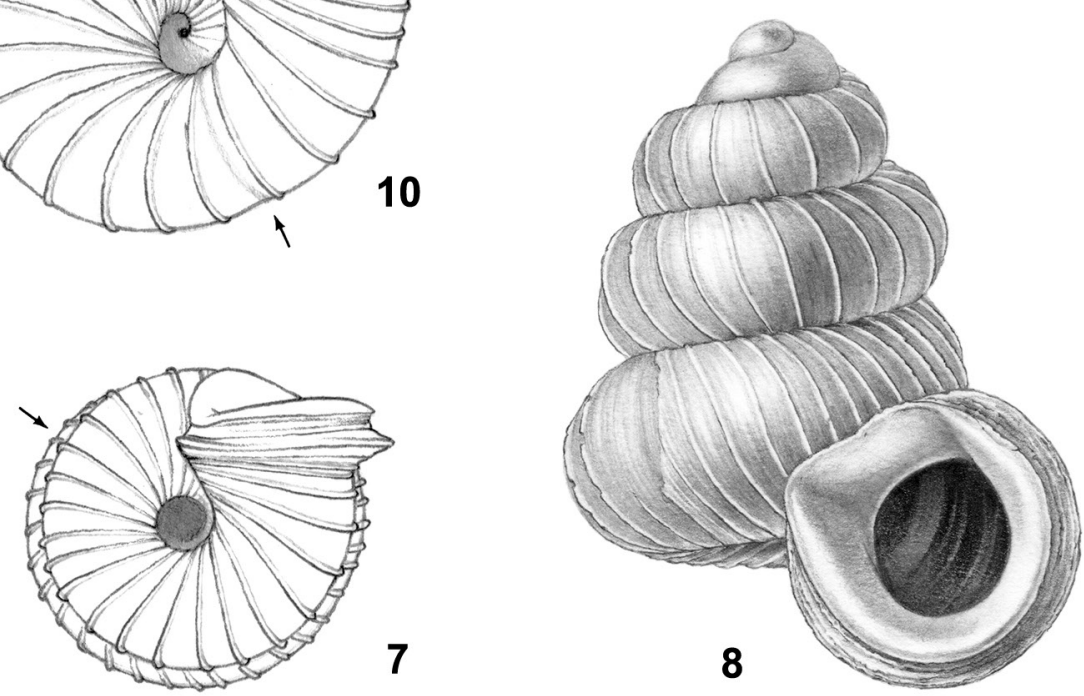

Figs 1-10. Arinia species: 1 - Arinia bathyodon sp. nov., holotype, frontal view, shell height $1.6 \mathrm{~mm}$; 2 - same shell, right lateral view; 3 - same shell, umbilical view; 4 - paratype, right lateral view with part of the shell wall removed to show internal tooth; 5 - Arinia congener sp. nov., holotype, frontal view, shell height $1.2 \mathrm{~mm}$; 6 - same shell, right lateral view; 7 - same shell, umbilical view; 8 - Arinia semiconica sp. nov., holotype, frontal view, shell height $1.8 \mathrm{~mm} ; 9$ - same shell, right lateral view; 10 - same shell, umbilical view. Arrows indicate the position of the constrictions. 
atal side not protruding beyond the penultimate whorl, columellar side not sinuous; outer peristome moderately spreading beyond the inner one on the palatal and basal side, gradually to abruptly narrowed on the columellar side, abruptly narrowed towards the upper corner; inner peristome just above the upper corner without protrusion, without furrow, palatal and basal side without lip parallel to the margin. Dimensions: height $1.0-1.2 \mathrm{~mm}$; width $0.75-0.80 \mathrm{~mm}$; height/width ratio 1.33-1.53; umbilicus $0.15-0.20 \mathrm{~mm}$ wide; number of whorls $41 / 8-4$ $3 / 8$, including tuba of c. $5 / 8$ whorl; aperture height $0.25-0.35 \mathrm{~mm}$; width $0.25-0.30 \mathrm{~mm}$.

Ecology. Steep limestone slopes with primary forest. Altitude c. $100 \mathrm{~m}$ a.s.l.

Distribution. Malaysia, Sarawak, Gunung Mulu N.P. Etymology. From 'congener' (Latin), 'of the same kind', referring to the fact it resembles $A$. similis from the same area.

\section{Arinia semiconica sp. nov.}

Figs 8-10

urn:Isid:zoobank.org:act:8E833C1F-3827-4663-9914-B7BB899E93C3

Examined material. Indonesia: Kalimantan Timur. Near Samarinda, Kampong Air Putih, 2004 (V12155/2 shells); Sangkulirang peninsula, Gua Ambulabung in the Baay river valley, 2004 (holotype: MZU.MOL.21.09, paratypes: V12154/>10); do., Tabalar river c. $50 \mathrm{~km}$ SE of Berau, 2004 (V12153/4). Diagnosis. A. semiconica sp. nov. resembles A. valkenburgi Vermeulen, 1996. Among the Borneo Arinia, the two share an almost strictly conical spire and a whorl count of 5 or less. A. semiconica differs in the absence of an oblique ridge on the inner peristome, in the angular corner of the aperture. In the key to the Borneo Arinia (VERMEULEN 1996) it keys out in a group of species including some with an approximately conical spire, albeit with distinctly more convex sides, such as A. ascotrochus Vermeulen, 1996, and A. obesa Vermeulen, 1996.

Description. Shell conical with almost flat sides, body whorl widest in frontal view. Whorls convex, body whorl often slightly more narrowly rounded at the periphery. Constriction present, without teeth. Tuba without teeth. Sculpture of radial, single-crested ribs, 3-6 ribs/0.5 mm. Spiral striation absent. Aperture slightly turned upwards or not. Peristome: palatal side distinctly protruding beyond the penultimate whorl, columellar side not sinuous; outer peristome spreading beyond the inner on the palatal and basal side, abruptly narrowed on the columellar side and towards the upper corner in fully adult shells; inner peristome just above the upper corner without protrusion, without furrow, palatal and basal side without lip parallel to the margin. Dimensions: height $1.7-2.3 \mathrm{~mm}$; width $1.45-1.70 \mathrm{~mm}$; height/ width ratio 1.13-1.35; umbilicus $0.15-0.25 \mathrm{~mm}$ wide; number of whorls $51 / 8-6$, including tuba of approx. $1 / 4$ whorl or slightly less; aperture height 0.40-0.55 mm; width $0.40-0.50 \mathrm{~mm}$.

Ecology. Primary forest on limestone bedrock, persistent in degraded vegetation and 10 years after fire, surviving in crevices in the rock. Altitude $0-300 \mathrm{~m}$ a.s.l.

Distribution. Indonesia, Kalimantan Timur, Sangkulirang peninsula, S-wards to Samarinda.

Etymology. From 'semi-' (Latin) half, here in the sense of 'more or less', and 'conicus', cone-shaped.

\section{Notharinia Vermeulen, Phung et Truong, 2007}

Note. Notharinia xenos sp. nov. (see below), has no trace of constriction in the spire with a thickened circular rim, as is typical of Arinia (see VERMEULEN et al. 2019: 168). It occurs on the fringe of the range of the genus Arinia (with numerous species along the eastern side of Borneo), and extremely distant from the known range of Notharinia (Laos and Cambodia, see PÁll-Gergely \& HunYAdi 2018, Vermeulen et al. 2019). We speculate that $N$. linnei Maassen, 2008 (see MAASSEN 2008) and A. micro Marzuki et Foon, 2016 (see MARZUKI \& FOON 2016), both from peninsular Malaysia, may have to be transferred to Whittenia Liew et Clements, 2020 (see LIEW \& ClEmENTS 2020). For reasons of parsimony, we prefer provisional placement in Notharinia based on shell morphology. Molecular phylogeny will have to shed light on the tenability of Notharinia next to Arinia.

\section{Notharinia xenos sp. nov.}

Figs 11-13

urn:Isid:zoobank.org:act:28C43827-AED9-4DEA-9464-954176674FAC

Examined material. Malaysia: Sarawak. 2nd Division, upper Tatau river valley, upper Kakus river limestone scarps, 2004 (holotype: MZU.MOL.21.10, paratypes: V12799/5 shells).

Diagnosis. Among Notharinia, N. xenos sp. nov. is identified by the somewhat thickened inner palatal peristome, close to the angular corner. Apart from the absence of a constriction, $N$. xenos is identified among the Borneo Arinia by the same character, in Arinia a thickened palatal peristome usually occurs in combination with a callosity on the parietal side, close to the angular corner. In some species of Arinia this structure may be inconspicuous and therefore resemble $N$. xenos, such as $A$. stenotrochus anisopleuron Vermeulen, 1996, which has a wider shell (height/ width ratio 1.6-1.9, versus 2.1-2.8).

Description. Shell cylindrical, slightly widened towards the base or not, rounded to truncated towards 
the apex. Apex oblique. Whorls moderately convex. Constriction absent. Sculpture of straight, low and thin, single-crested, closely spaced radial ribs, 8-15 ribs $/ 0.5 \mathrm{~mm}$, on the body whorl and particularly towards the aperture somewhat wider spaced. Spiral striation absent. Aperture attached to the penultimate whorl, not turned upwards, slightly obliquely drop-shaped with the upper corner narrowly rounded. Peristome double: outer peristome moderately spreading beyond the inner on the palatal and basal side, gradually to rather abruptly narrowed on the columellar side, abruptly so towards the upper corner; inner peristome slightly to distinctly protruding from the outer one, with few lamellae on the outer surface, along the inner edge of the palatal side thickened with a rounded callus, which rather abruptly starts just below the upper corner of the aperture and then, lower down, gradually merges with the inner peristome, inner peristome along the palatal and basal side without lip parallel to the margin. Umbilicus closed. Dimensions: height 1.9-2.4 mm; width 0.85$0.90 \mathrm{~mm}$; height/width ratio 2.11-2.82; number of whorls $41 / 4-47 / 8$, including tuba of $3 / 8-1 / 4$ whorl; aperture height $0.40-0.55 \mathrm{~mm}$; width $0.40-0.50 \mathrm{~mm}$. Ecology. Primary forest on limestone bedrock. Altitude $100-400 \mathrm{~m}$ a.s.l.

Distribution. Malaysia, Sarawak, limestone ranges in upper Kakus valley.

Remark. The absence of a constriction in the form of a thickened circular rim on the inner surface of the shell was ascertained by breaking up two shells and immersing the others in gasoline, which temporarily makes them translucent.

Etymology. From ' $\xi \dot{\varepsilon} v o \zeta^{\prime}$ (Ancient Greek) foreigner, applied as a noun in apposition.

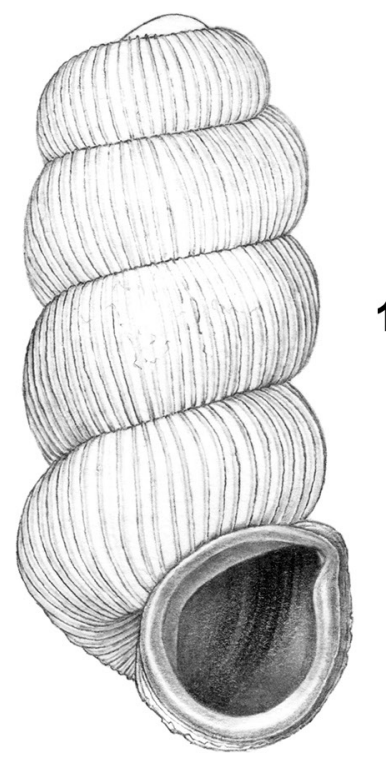

11

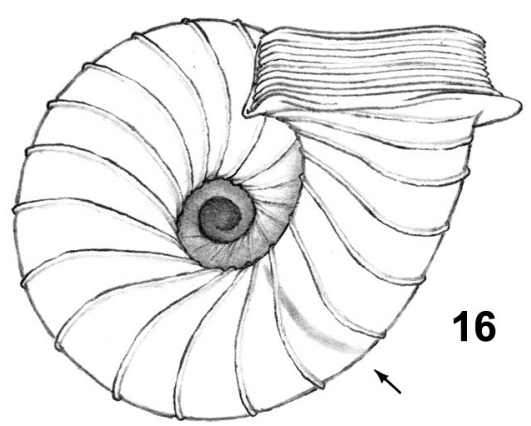

16

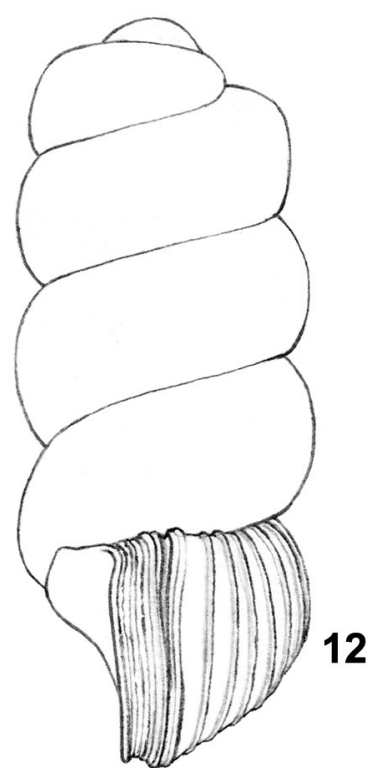

15
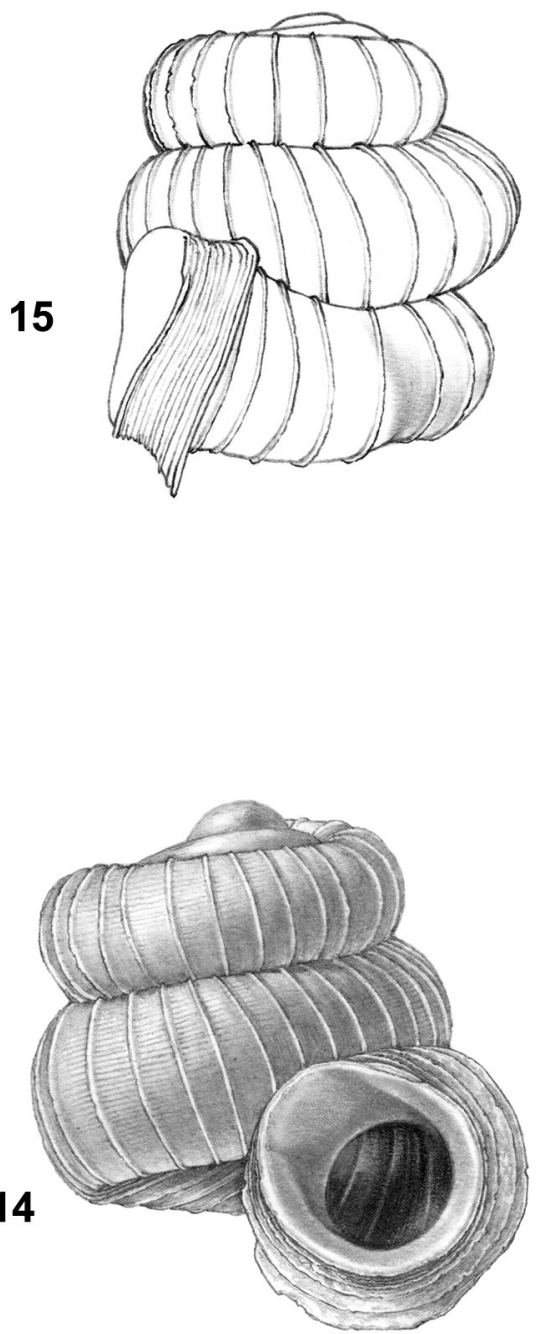

Figs 11-16. Notharinia and Opisthostoma species: 11 - Notharinia xenos sp. nov., holotype, frontal view, shell height 1.9 mm; 12 - same shell, right lateral view; 13 - same shell, umbilical view; 14 - Opisthostoma hemituba sp. nov., holotype, frontal view, shell height $1.6 \mathrm{~mm}$; 15 - same shell, right lateral view; 16 - same shell, umbilical view. Arrow indicates the position of the constriction. 
Opisthostoma W. T. Blanford et H. Blandford, 1860

Note. See Vermeulen (1994) for a revision of the Borneo species. Since then, arguments to segregate Plectostoma from Opisthostoma have been given in LIEW et al. (2014). Species 1 to 23 in VERMEULEN (1994) are retained within the narrower delimitation of Opisthostoma, all others are Plectostoma.

\section{Opisthostoma hemituba sp. nov.}

Figs 14-16

urn:Isid:zoobank.org:act:DA834F5B-341F-45F1-9D0A-25F570F7E10B

Examined material. Indonesia: Kalimantan Timur. Sangkulirang peninsula, Gua Mardua near Kampong Pengadan, 2004 (holotype: MZU.MOL.21.11, paratypes: V12150/>10 shells).

Diagnosis. A species of the genus Opisthostoma (exclusive of Plectostoma) because of its low whorl count, its shortly cylindrical spire, its small size, and its tuba which is curved around an axis different to the one of the spire. Within the genus, it is identified by its short tuba, which is so short that the aperture is on the right side of the dextrally coiled spire in frontal view, rather than on the left side as in other Opisthostoma. It is also identified by the slight curvature of the tuba, which covers no more than approx. $1 / 8$ of a whorl $(1 / 4$ of a whorl or more in other Opisthostoma). Finally, the coiling axis of the tuba is approx. perpendicular to the coiling axis of the spire, so that the tuba bulges slightly downwards in right or left lateral view, but in umbilical view the deviant coiling of the tuba is hardly visible (in other Opisthostoma the coiling axis of the tuba is oblique to the coiling axis of the spire and conspicuously different).

Description. Spire approx. shortly cylindrical with the body whorl widest in frontal view, to depressed conical. Apex oblique, truncated. Whorls moderately

\section{REFERENCES}

ADAmS H., ADAmS A. 1854-1858. The genera of recent Mollusca 2. John van Voorst, London.

Blanford W. T., BlanFORD H. F. 1860. Contributions to Indian malacology, No. I. The Journal of the Asiatic Society of Bengal 29: 117-127.

LIEw T.-S., Clements G. R. 2020. Whittenia, a new genus of land snails from Perak, Peninsular Malaysia (Gastropoda: Diplommatinidae). Raffles Bulletin of Zoology Supplement 35: 143-148. https://doi.org/10.26107/RBZ-2020-0047

Liew T.-S., Vermeulen J. J., MARZUKI M. E., SCHILTHUizeN M. 2014. A cybertaxonomic revision of the micro-landsnail genus Plectostoma Adam (Mollusca, convex, rounded, body whorl rather narrowly rounded at the base, towards the constriction. Constriction without teeth, or with an inconspicuous transverse columellaris. Tuba short, approx. 1/8 whorl, so short that the aperture is on the right side of the dextrally coiled spire in frontal view, only slightly curved, attached to the spire, hardly narrowed towards the constriction, approx. circular in section, somewhat narrowly rounded below. Sculpture of low and thin radial ribs, widely spaced on the spire (3-5 ribs/0.5 $\mathrm{mm})$, but towards the tuba and on the tuba even wider spaced (2-3 ribs $/ 0.5 \mathrm{~mm})$. Spiral striation fine. Aperture tilted 5-30 degrees in relation to the coiling axis of the spire, circular, teeth absent; outer peristome distinctly spreading beyond the inner one except on the parietal side; inner peristome distinctly protruding from the outer one, somewhat thickened but hardly spreading. Dimensions: height of spire $1.6-1.7 \mathrm{~mm}$; width $1.60-1.75 \mathrm{~mm}$; height/width ratio 0.91-1.06; height of spire without tuba 1.0-1.1 $\mathrm{mm}$; width without tuba $1.25-1.40 \mathrm{~mm}$; height/ width ratio of spire without tuba $0.71-0.85 \mathrm{~mm}$; umbilicus $0.28-0.35 \mathrm{~mm}$, or $21-26 \%$ of the shell width without tuba; number of whorls $33 / 4-4$, excluding tuba of approx. 1/8 whorl or slightly more; aperture height $0.30-0.45 \mathrm{~mm}$; aperture width $0.4-0.5 \mathrm{~mm}$.

Ecology. Persistent 10 years after massive forest fire in a degraded vegetation of Piper, Lantana, Eupatorium, and Mallotus on a limestone cliff. Altitude c. $100 \mathrm{~m}$ a.s.l.

Distribution. Indonesia, Kalimantan Timur, Sangkulirang peninsula.

Remark. Resembles the genus Arinia at first sight, until the slight curvature of the short tuba is appreciated. Apart from this, the short-cylindrical, apically truncated spire is rather typical of Opisthostoma, less so of Arinia.

Etymology. From the prefix 'hemi-' (Latin) half, and 'tuba', a trumpet, referring to the short tuba.

Caenogastropoda, Diplommatinidae), from Peninsular Malaysia, Sumatra and Indochina. ZooKeys 393: 1-107. https://doi.org/10.3897/zookeys.393.6717

MAASSEN W. J. M. 2008. A new species of the genus Notharinia Vermeulen, Phung \& Truong, 2007 from Peninsular Malaysia (Mollusca, Caenogastropoda, Pupinidae). Zoologische Mededelingen 82(1-23): 109112.

MARZUKI M. E. BIN, FOON J. K. 2016. A new land snail, Arinia (Notharinia) micro (Caenogastropoda: Cyclophoroidea: Diplommatinidae), from a limestone karst in Perak, Peninsular Malaysia. Raffles Bulletin of Zoology 64: 313-318. 
PÁll-Gergely B., HunYADI A. 2018. Four new cyclophoroid species from Thailand and Laos (Gastropoda: Caenogastropoda: Alycaeidae, Diplommatinidae, Pupinidae). Zoosystema 40: 59-66.

https://doi.org/10.5252/zoosystema2018v40a3

VERMEULEN J. J. 1994. Notes on the nonmarine molluscs of the island of Borneo 6. The genus Opisthostoma (Gastropoda Prosobranchia: Diplommatinidae), part 2. Basteria 58: 73-191.

https://natuurtijdschriften.nl/pub/597042

VERMEULEN J. J. 1996. Notes on the nonmarine molluscs of the island of Borneo 8. The genus Arinia; additions to the genera Diplommatina and Opisthostoma (Gastropoda Prosobranchia: Diplommatinidae). Basteria 60: 87-138. https://natuurtijdschriften.nl/pub/597094

VERMEUlen J. J., LIEW T.-S. 2022. Handbook to the land snails and slugs of Sabah and Labuan island. Institute for Tropical Biology and Conservation, Universiti Malaysia Sabah, Kota Kinabalu.
Vermeulen J. J., LuU H. T., Keum T., ANker K. 2019. Land snail fauna of the Mekong Delta limestone hills: Notharinia Vermeulen, Phung \& Truong, 2007, and a note on Plectostoma A. Adams, 1865 (Mollusca: Gastropoda: Caenogastropoda: Diplommatinidae). Folia Malacologica 27: 167-177. https://doi.org/10.12657/folmal.027.015

Vermeulen J. J., Phung C. L., Truong Q. T. 2007. New species of terrestrial molluscs (Caenogastropoda, Pupinidae \& Pulmonata: Vertiginidae) of the Hon Chong - Ha Tien limestone hills, southern Vietnam. Basteria 71: 81-92.

https://natuurtijdschriften.nl/pub/597339

Received: October 28th, 2021

Revised: December 18th, 2021

Accepted: January 7th, 2022

Published on-line: March 2nd, 2022 